\title{
Financial Development and Economic Growth: Evindence From Azerbaijan
}

\author{
ILKIN MAMMADOV \\ Department of Economics and Business Administration \\ Azerbaijan State University of Economics (UNEC) \\ AZERBAIJAN \\ FARIZ AHMADOV \\ Department of Economics and Business Administration \\ Azerbaijan State University of Economics (UNEC) \\ AZERBAIJAN
}

\begin{abstract}
The impact of financial development on economic growth has always been an important issue. Especially when financial crises occur, the relationship between financial markets and financial crises and economic activities is on the agenda. The main purpose of this study is to determine the relationship between financial development and economic growth in the Azerbaijani economy. For this purpose, VECM model estimation and Granger causality analysis was performed by taking monthly data between 2005-2019. As a result of the analysis, it was revealed that there is a two-way relationship between financial development and economic growth in Azerbaijan.
\end{abstract}

Key words: - financial development, economic growth, financial markets, GDP, VECM, Granger Causality Received: June 23, 2020. Revised: November 2, 2020. Accepted: December 29, 2020. Published: January 14, 2021

\section{Introduction}

When the economic literature is examined, the phenomenon of economic growth is one of the issues that attract attention in every period. Different economic growth performances of countries are effective in keeping this interest alive. This situation prompted economists to explain why countries show different growth performance. Recently, whether the financial system is an important determinant of the economic growth process has become one of the issues discussed in the literature. Many economists even see financial development as one of the main factors for the growth of the real economy.

The main function of the financial system is to transfer funds from units that have excess funds in the economy to units that need funds. The financial system fulfils this function through financial instruments, intermediaries and legal regulations that shape the behavior of these units. Increasing and developing financial intermediaries, creating new financial instruments, and making the financial system stable with new legal regulations is necessary for both the development of the financial system and for feeding the real economy.

The development of the financial sector includes both financial expansion and financial deepening. While financial expansion is related to the spread of financial services and the growth of financial institutions, financial deepening can be expressed as per capita financial services and an increase in the ratio of institutions or financial assets to income. The development of the financial sector through the expansion or diversification of financial markets provides better allocation of resources.

The relationship between financial development and economic growth has been frequently analyzed in the literature and is still being analyzed. According to some researchers, financial development plays an important role for economic growth, while for others it can be considered unimportant. Schumpeter [83] claims that banking activities are the engine of economic growth. However, Robinson [78] states that the key factor that financial development follows economic growth is the initiatives put into operation. In addition, Lucas [63] thinks that the role of the financial sector is exaggerated. The first empirical study in this field belongs to Goldsmith [45] and states that there is a positive relationship between per capita income and financial development. The literature is examined under three headings according to the direction of the causality relationship. The first is the supply-leading approach, which argues that financial development based on Schumpeter [82] positively affects economic growth. According to this approach, the 
financial system plays a key role for economic growth. The financial system, which effectively fulfils its intermediary function, increases the economic growth by meeting the funding requirements required for investments. The relationship is one-way and from the financial system to economic growth. The second is the demand-following approach, starting with Robinson [78] and stating that financial development follows economic growth. The direction of the relationship is from economic growth to financial development. In addition, there are studies such as Demetriades and Hussein [29] advocating that there is a two-way causality relationship between financial development and economic growth, both supply-driven and demanddriven. The third emphasizes that there is no causal relationship between financial development and economic growth, as concluded from Lucas' [62] study.

\section{Literature Review}

In the literature, it is the dominant view that financial development positively affects economic growth. It can be said that the relationship between the development of the financial system and economic growth was first mentioned by Smith. Another economist who clearly stated that the financial sector would favorably support economic growth was Joseph Schumpeter. Schumpeter, in his study in 1912, suggested that the well-functioning banking system played a role in economic growth by encouraging entrepreneurs to use new technologies that enable the most efficient ways of production [82]. In the following years, the view that financial development positively affected economic growth was supported by studies by Goldsmith [45], McKinnon [66], Fry [43], Bencivenga \& Smith [20], King \& Levine, [57] and King \& Levine [58].

Although the view that financial development will cause economic growth is dominant, there have been economists who have adopted the view that this relationship is exaggerated and there is no remarkable link between the two variables. In this context, Robinson's work in 1952 and Lucas' work in 1988 draw attention. According to Robinson and Lucas, economic growth consists of two basic sources, physical and human capital, and financial development has no significant impact on these two sources [36]. Some of the studies investigating the relationship between economic growth and financial development concluded that both variables affect each other simultaneously. The prominent among these studies can be listed as
Demetriades, Hussein [29], Shan, Morris, \& Sun, [85] and Al-Yousif [6].

Pioneering studies examining the relationship between financial development and economic growth were initiated by Schumpeter [81], Gurley and Shaw [48], Goldsmith [45], Patrick [75], McKinnon [66], and Shaw [86]. King and Levine [54] made a great contribution in the development of studies on this topic. In their study, they used annual financial development indicators, growth rates and physical capital accumulation data in 80 countries for the period of 1960-1989; they concluded that there was a strong and positive relationship between economic growth and the other variables in the long run. The criteria which were used for financial development in this study, have been widely used in other studies [7].

Wolde-Rufael [89] investigated the relationship between economic growth and financial development by using the VAR analysis in Kenya for the period 1966-2005. Findings have shown that financial development promotes economic growth in Kenya and that policies to strengthen the development of the financial sector can contribute to economic growth.

Anwar and Sun [8], showed that the level of financial development in Malaysia significantly affected the domestic capital stock that contributed to economic growth using the GMM (Generalized Moments Method) for the period 1970-2007. However, they observed that the direct effect of the level of financial development on economic growth in Malaysia is statistically insignificant.

Zhang et al. [91] examined the relationship between financial development and economic growth at the city level in China for the period 2001-2006 using the GMM method. The results showed that there is a positive relationship between economic growth and the financial sector. It has been determined that the size and depth of the financial sector promotes economic growth.

Shahbaz et al. [84] explained the effects of economic growth, coal consumption and trade openness on financial development by using Bounds Test in South Africa in the period of 19652008. It is concluded that economic growth and financial development are co-integrated.

Menyah et al. [67], 1965-2008 investigated the relationship between financial development and economic growth in 21 African countries with Bootstrap Panel Causality Test. It has been observed that financial development supports economic growth to a limited extent.

Samargandi et al. [80] analyzed the relationship between financial development and economic 
growth in 52 middle income countries in the period 1980-2008 by using the average group estimates pooled in the dynamic heterogeneous panel. In the long term, it was observed that there is an inverted U-shaped relationship between finance and growth, and in the short term, the relationship is insignificant.

Luintel et al. [63], in their research conducted by Bayesian method in 69 countries during the period of 1989-201, found that there was a significant relationship between economic growth and financial development in high-income countries. In middle and low-income countries, it does not exist.

Atje and Jovanovic [13] concluded that stock markets and bank loans positively affected economic activities in their studies in which 94 countries used annual data for the period 19601985. Similar results were consistent with the findings obtained in studies by Demirgüç-Kunt and Maksimovic [30] and Levine and Zervos [61].

According to the causality hypothesis, supplyled growth takes place in the early stages of economic development, financial opportunities such as diversification of financial instruments and services, mobilizing savings and providing capital accumulation stimulate the increase in investments. After this stage, causality emerges from economic growth to financial development and a demanddriven growth hypothesis takes place [23].

Arestis et al. [9], using quarterly data covering 1972-1998 period, investigated the relationship between financial development and growth in Germany, USA, Japan, England and France by cointegration and error correction model methods. They found that developments in the bank and stock markets increased economic growth. In addition, Arestis et al. [10] analyzed the relationship between financial development and growth in countries covering South Korea, the Philippines, Thailand, Greece, India and Egypt, using annual data for the period 1955-1997, using different variables and cointegration and error correction model methods. In the study, they found that only four out of six countries had positive and significant effects of real interest rates on financial development in the long run.

Al-Yousif [6] investigated the relationship between the data of 30 developing countries and financial development and economic growth for the period 1970-1999 by using panel method and Granger causality test. Although the research finds that the causality between financial development and economic growth is in both directions, it has reached the conclusion that the relationship between financial development and economic growth cannot be generalized.

Beck et al. [17] used the generalized OLS method in their study with annual data covering 77 countries for the period 1960-1995. As a result of the study, they found that financial intermediation has a positive effect on total factor productivity and GDP growth, whereas this effect is weak on physical capital increase and savings.

Henry [50] tested whether liberalization in stock markets increased investments by using panel data method in 11 developing countries (Brazil, Argentina, Chile, Colombia, India, Korea, Malaysia, Mexico, Philippines, Thailand, and Venezuela) using annual data from 1970-1990 period. As a result of the study, it was concluded that liberalization in the stock market increased private sector investments in 9 of the 11 countries examined.

Levine et al. [61] investigated whether financial intermediation had an impact on economic growth and whether the countries' creditor rights and surveillance and control systems could explain financial development with annual data for 74 countries between 1960-1995. In the study using dynamic panel techniques, they concluded that financial intermediation development accompanied economic growth, and that the improvement in the legal and accounting systems of countries along with financial development accelerated economic growth.

Müslümov and Aras [69] investigated the relationship between capital market development and economic growth in 22 OECD countries between 1982-2000 using panel method and causality tests. In the study, capital market capitalization and liquidity indicators are used as a proxy for capital market development. As a result of Granger causality tests, it was found that the development of the capital market caused economic growth.

Fink et al. [41] examined the effects of bond market development on economic growth in the period of 1950-2000 in 13 developed countries. In their study, which included Granger causality test and cointegration analysis, it was revealed that the development of the bond market affected the real economic activity. In the study, they achieved results that supported the demand-following and supply-led approach in Italy, Japan and Finland, the supply-led approach in the USA, Germany, Austria, England and Switzerland, and the weak supply-led approach in the Netherlands and Spain.

Bhattacharya and Sivasubramanian [21] have demonstrated the existence of a causality from M3 
(as a proxy for financial development) to national income in their study, where they examine the causal relationship between financial development and economic growth for India.

Calderon and Liu [23] investigated the relationship between financial development and economic growth in the 1960-1994 period in 109 developed and developing countries, using the ratio of money supply to national income and the ratio of loans to the private sector to the national income as a proxy for financial development. In the research findings, it was concluded that financial development affects economic growth positively through capital accumulation and productivity.

Christopoulos and Tsionas [27], examined the relationship between financial depth, which was considered as a proxy of financial development, and economic growth in 10 developing countries including Colombia, Paraguay, Peru, Mexico, Ecuador, Honduras, Kenya, Thailand, Dominican Republic and Jamaica using the panel cointegration method with annual data for the period 1970-2000. As a result of the analysis, a long-term relationship between financial development and economic growth and a strong causality from financial development to economic growth was found.

Beck and Levine [16] investigated the relationship between financial development and economic growth in 40 countries using panel method between 1976-1998. They used different variables as an indicator of financial development, transaction volume and market capitalization, as indicators of development of stock markets, bank loans as financial indicators for the banking sector. As a result of the estimation, they showed the existence of a relationship between financial development and economic growth.

Dritsakis and Adamopoulos [33] investigated the relationship between financial development and economic growth using a cointegration model for Greece using quarterly data from 1960 to 2000. In the model, there is a cointegration relationship between financial development and economic growth. They also revealed that there is a causal relationship between financial development, economic openness, and economic growth in the error correction model.

Rioja and Valev [77] concluded that financial development affects economic growth by accelerating the increase in productivity in countries with high levels of welfare and accelerates capital accumulation in developing countries with low levels of financial development, using panel data in 74 countries between 19611995.
Caporale et al. [24] analyzed the stock market and economic development for the 5 Southeast Asian countries in accordance with their internal growth models with quarterly data between the first quarter of 1979 and the fourth quarter of 1998, using Toda-Yamamoto causal methods. In the model, gross fixed capital accumulation (as a ratio to nominal GDP), investment efficiency and as financial development indicator two criteria (market capitalization rate and the value of shares traded on the stock market) were used. As a result of the model, it has been revealed that the capital market contributes to economic growth by increasing investment efficiency.

Chang and Caudill [26] tested supply-led and demand-following approaches for financial development and economic growth in Taiwan for the period 1962-1998. In the study, per capita income as per dependent variable, independent variables M2GDP as a measure of financial development, import and export were used. As a result of the Granger causality test, it was observed that there was a one-way causality from financial development to economic growth, and it was concluded that the supply-led approach was applied in Taiwan.

McCaig and Stengos [65] analyzed the relationship between financial intermediation development and economic growth in their study using the annual data for 71 countries between 1960-1995. When local private loans or liquid liabilities are used as a financial development criterion, it is revealed that the development in financial intermediation has a strong and positive effect on growth.

Ndikumana [71] found that financial intermediation affected investments in 99 countries by using panel data for 1965-1997. In the study, it was emphasized that the practices of reducing the financial intermediation transaction costs by the countries and strengthening the rights of creditors and investors will encourage investments by facilitating the development of banks and exchanges.

Rousseau and Vuthipadadorn [79], analyzed the existence of effect of financial intermediation on investments and growth using error correction model and causality tests 10 Asian countries (India, Indonesia, Japan, Korea, Malaysia, Pakistan, Philippines, Singapore, Sri Lanka and Thailand) for 1950-2000 period. The model results show that financial development is a driving force for investments, and there is a one-way relationship from financial development to investments in most countries. 
Ang and McKibbin [7] analyzed the relationship between financial development and economic growth in Malaysia, using cointegration and causality methods with annual data for the period 1960-2001. In the study, they found that financial liberalization stimulated development in the financial sector, there was a positive relationship between financial depth and economic growth, and growth in the long run increased financial depth.

Shahbaz et al. [83], in their study for Pakistan between 1971-2006, investigated the relationship between the development in stock markets and economic growth by cointegration method. The results of the study showed that there is a strong relationship between the development in the stock market and economic growth, and there is a bidirectional causality between stock market development and economic growth.

Abu-Bader and Abu-Qarn [1] investigated the relationship between financial development and economic growth in the Middle East and North African countries for the period 1960-2004, including Algeria, Egypt, Israel, Morocco, Syria and Tunisia, using the VAR method and Granger causality tests. Strong results supporting the supply-led hypothesis, suggesting that financial development led to economic growth in five of the six countries, were found in the study. For only Israel, a causality from economic growth to financial development has been found.

Enisan and Olufisayo [38] investigated the relationship between the development of the stock market and economic growth in seven lower Sahara countries using the ARDL Bounds test method. In the study, they determined that there is a cointegration relationship between the development of the stock market and economic growth in Egypt and South Africa, and they showed that the development in the stock market has a positive effect on economic growth. Granger causality tests have revealed that the development in the stock market has led to economic growth in Egypt and South Africa.

Kar and Pentecost [55], analyzed the relationship between financial development and economic growth in Turkey for the 1963-1995 period using cointegration and error correction methods with annual data. In the study, they used the change in national income per capita as a dependent variable, and five different indicators of financial development as the explanatory variable (money supply as a ratio to national income, bank deposits, loans extended to the private sector, domestic loans total, and the ratio of private sector loans in domestic loans). In the study, they concluded that the direction of financial development and economic growth may change depending on the selected financial development indicator.

King and Levine [58] tested Schumpeter's view to measure the relationship between financial development and economic growth in their study using data from 80 countries for the period 19601989. A strong correlation was found between various variables that measure the level of financial development, and GDP per capita and growth rate. It is concluded that financial services encourage economic growth by increasing capital accumulation and efficiency.

Gregorio and Guidotti [46] analyzed the longterm relationship between financial development and economic growth, and loans given by the banking system to the private sector were used as indicators of financial development. A positive correlation was found between this variable and GDP, and this effect was observed to vary from country to country. In the study conducted for Latin American countries, the result of this correlation was negative. The results obtained reveal that the effect of financial development on economic growth is through productivity channel rather than investment channel.

Naceur and Ghazouni [70] analyzed the relationship between finance and economic growth by using unbalanced panel analysis for 11 MENA countries. The impact of financial development on growth has been addressed in terms of both banking and capital markets. According to the results, a negative or insignificant effect of financial development on economic growth has emerged. The underdeveloped financial system is shown as the reason for this effect. The necessity of improving the functions of the banking sector in the MENA region and strengthening the banking within the institutional framework was put forward as a policy proposal.

Bozoklu and Y1lanc1 [22] investigated the relationship between financial development and economic growth for 14 developing countries in the period of 1988-2011 using the Panel Granger causality test developed by Dumitrescu-Hurlin. According to the results, it was observed that financial development caused strong economic growth. In addition, it was concluded that financial systems of these countries should be developed in line with their growth targets.

Aydin et al. [14] determined the relationship between financial development and economic growth in the 1990-2009 period for 14 developing countries through panel data analysis. 5 different 
variables were used as an indicator of financial development, and according to the findings, it was revealed that the savings should be integrated into the financial system through the capital market rather than the banking sector. In addition, increasing the competition between financial institutions and decreasing the net interest margin can contribute positively to economic growth.

Aydın and Malcıoğlu [15] analyzed the relationship between financial development and economic growth using Dumitrescu-Hurlin Panel Causality test in their study. In this study, in which OECD countries were analyzed in the 1980-2014 period, loans given by the financial sector were used as an indicator of financial development. According to the findings, causality was determined from financial development to economic growth, but no causality from economic growth to financial development was found.

Fink et al. [40] analyzed the years between 1996 and 2000 to see the effect of credit, bond and stock markets in 9 transformation economies, which are members of the EU, on the economic growth. They stated that transformation structure varies between countries, and financial structures (except the stock market), where public sector support is available, have a positive effect on economic growth and financial stability.

Winkler [88] states that a strategy that operates with the logic that allowing foreign banks to enter the sector will provide financial stability in order to achieve financial development as a result of the study on Southeast European countries.

Caporale et al. [24] analyzed 10 newly transformed economies in the EU using the dynamic panel data method for the period 19942007. They state that the stock and credit markets in these economies have not yet developed and their contribution to economic growth is limited as they lack financial depth. In line with the findings, they have obtained from the application, the banking sector is the most influential contributor to economic growth. The relationship between the variables is one-way and from financial development to economic growth.

Akimov et al. [4] examined the 1984-2004 period using fixed effects and dynamic panel tests for 27 developed and emerging transformation economies. They stated that, contrary to some studies, they found a positive and strong relationship between economic growth and financial development.

Soultanaeva [87] analyses the relationship between financial development and economic growth using quarterly data for three Baltic countries: Latvia, Estonia, and Lithuania. The author, who preferred the VAR (Vector Autoregressive Model) method in her study of 1995-2008 period, later used the bootstrap critical values by Li and Maddala (1997). As a result of the findings obtained from the application, it indicates that a development in the banking sector may lead to economic growth in the long term.

Cojacaru et al. [28] tested the former communist Central and Eastern European countries and Commonwealth of Independent States countries using the GMM method to understand the impact of financial development on economic growth. They used many variables as proxy for financial depth and effectiveness in their studies covering the period of 1990-2008. The results they obtained from the study; private sector loans positively affect economic growth, but in the presence of high inflation rates, this positive effect becomes statistically insignificant. High interest rates prevent economic growth by reducing inter-bank competition.

Ağayev [2] analyzed the relationship between financial development and economic growth for 20 transition economies. In his study, which covers the period of 1995-2009, the Pedroni co-integration test was applied using the data obtained from the World Bank. The level of financial development is represented by the share of the banking sector loans in GDP and the economic growth is represented by increase in real GDP growth. The application findings indicate the supply-led growth, that is, the relationship between the variables is from financial development to economic growth.

Dudian and Popa [34] analyzed the relationship between financial development and economic growth for eight Central and Eastern European countries with transformation economies in their studies, which they excluded Slovenia and Slovakia from the analysis due to data constraints. The variables they take to measure financial development, the broad defined money annual growth rate, the share of domestic loans to the private sector in GDP, the share of interest rate and non-performing loans in total loans. The dependent variable is the annual GDP growth rate. Variables were obtained from the World Bank data base. Findings obtained by developing four different scenarios and testing the relationship between variables; bad loans and a spread in interest rates have an important and negative impact on economic growth. Contrary to the increase in the private domestic loan share, an increase in the private sector loan growth rate and the money supply (M2) affects GDP positively. 
Akınc1 et al. [5] analyzed the period 1980-2011 for the OECD member countries using Pedroni and Kao cointegration test; They found that there is a long-term co-integration relationship between financial development and economic growth. According to Granger panel causality analysis, causality relationship between variables is demandfollowing.

Petkovski and Kjosevski [76] tested 16 countries using the GMM method in their studies on Central and Southeast European Transformation economies. Variables representing financial development were private sector loans, interest rates and money-like assets. According to the findings obtained from the data belonging to 19912011 period; While the margin between private sector loans and interest rates negatively affects economic growth, the effect of money-like assets on economic growth is positive.

Obradović and Grbić [72] analyzed the relationship between financial development and economic growth using quarterly data covering the period of 2004-2011 for Serbia. In the empirical part they used Todo-Yamamoto causality analysis and stated that economic growth contributes to financial deepening. They also emphasize that there is a unilateral causality relationship from the share of private entrepreneurs and household loans in GDP to economic growth. There is a bilateral causality relationship only between the share of the non-financial private sector in total domestic loans and economic growth.

Lawal etc. [60] in their research used ARDL related forecast techniques to study the existence of cointegration between economic growth, financial development, and trade openness in Nigeria. The results show that there is a two-way integration between economic growth and financial development, on the other hand, between economic growth and trade openness. In this paper used the ARDL model for the existence of cointegration between variables or for other types of analysis. In our analysis, real gross domestic product (RGDP), the proxy for economic growth, net credit to the private sector (NDC) as a percentage of GDP, and stock turnover rate (STR) as a percentage of GDP were used. While the supply (M2) represents variables for measuring financial development as a percentage of GDP, the openness of trade is the proxy for total foreign trade (TRD) as a percentage of GDP.

Oskonbaeva [73], research the causal relationship between financial development, trade openness and economic growth. The empirical analysis of this study consists of panel data of 9 transition countries (Ukraine, Armenia, Azerbaijan, Belarus, Georgia, Kazakhstan, Kyrgyzstan, Moldova, and Tajikistan) in the period 1998-2015. To investigate the causality relationship between financial development and economic growth, threestage Panel Granger causality test was used. The results show that there is evidence of bilateral causality between financial development and economic growth in the short term. Policy makers in transition countries should consider the impact of financial development on economic growth.

Belazreg, and Mtar, [18] Using the panel vector auto-regressive model and examine interactions between the openness of trade, innovation, financial development and economic growth in 27 OECD countries between 2001-2016. The results show that there is a neutral relationship between economic growth and innovation, innovation and financial development, and innovation and trade.

In recent years, several studies have been conducted in Azerbaijan, especially on financial development and economic growth. Brief information about some of these studies is given below.

Humbatova etc. [51] examines the relations between GDP in Manat and Dollar and total electric energy consumption (1995-2017) for the last 22 years in the Republic of Azerbaijan. Besides, the relations between the electric energy consumption and the growth of GDP in these sectors were analyzed. Autoregressive distributed lag model was used as a research methodology. Stationary tests of variables (ADF, PP, and KPSS) and Pairwise Granger Causality Tests were done. Stability of models was examined. Eviews_9 econometric software program was used to establish graphics and do calculations. Result of research there is a positive correlation not only in GDP and electric energy consumption but also electric energy consumption and GDP in different sectors of economy.

Akbulaev and Huseynova [3] research the relationship between the domestic credit volume and the gross domestic product in the public and deposit banks were analyzed by using the quarterly data covering the periods of 2006-2017 for Azerbaijan. The reason for selection of 2006-2017 period is to release process of the New Azerbaijani Manat in the Republic of Azerbaijan in 2006. As a result of the analysis, it was concluded that each of them was first-order stationary series and there was no long-run relationship between them. Eventually, the result of Granger causality test, which is applied for credit volume and economic growth, has a 
bidirectional causality relationship between two series.

Mukhtarov etc. [68]in their paper investigates the impact of government education expenditures on economic growth in Azerbaijan during 19952017 using the Vector Error Correction Model (VECM). Since the study uses time series variables the unit root properties of employed variables are tested for non-stationarity. Stationarity of the data is tested using conventional Augmented DickeyFuller test. Different cointegration methods, namely, Johansen, DOLS, FMOLS and CCR are used to get more robust results. The results from cointegration methods are consistent with each other and confirm existence of long-run relationship among the variables. This implies that there is a long run relationship between government expenditures on education and economic growth in Azerbaijan. To test the quality of the model residuals of the model are tested for the serial correlation, heteroskedasticity, and normality. The model is checked for model misspecification and stability. The results of all above mentioned tests are found to be adequate. Moreover, estimation results of VECM show that government expenditures on education has positive and statistically significant impact on economic growth in the long run.

\section{Data and Methodology}

In this study, the effect of financial expansion on Gross Domestic Product between 2005-2019 will be tested. The data set consists of 183 observations covering the time between January 2005 and October 2019. The data were obtained from the Central Bank of Azerbaijan. The variables to be used in the econometric model are given in the table below.

Table 1: Variables

\begin{tabular}{|l|l|l|}
\hline \multicolumn{1}{|c|}{ Variable } & $\begin{array}{l}\text { The role of } \\
\text { the variable } \\
\text { in the model }\end{array}$ & Description \\
\hline LOGGDP & $\begin{array}{l}\text { Dependent } \\
\text { variable }\end{array}$ & $\begin{array}{l}\text { Gross } \\
\text { Domestic } \\
\text { Product }\end{array}$ \\
\hline LOGM3GDP & $\begin{array}{l}\text { Independent } \\
\text { variable }\end{array}$ & $\begin{array}{l}\text { The weight of } \\
\text { M3 money } \\
\text { supply in GDP }\end{array}$ \\
\hline LOGFCFDGDP & $\begin{array}{l}\text { Independent } \\
\text { variable }\end{array}$ & $\begin{array}{l}\text { The weight of } \\
\text { FCFD loans in } \\
\text { GDP }\end{array}$ \\
\hline
\end{tabular}

If we examine the economic model to be established in accordance with its theoretical basis, it is an opinion that the macro financial data of the country has an impact on GDP, which is accepted by theory and has been tested with empirical studies. The variable found with the ratio of M3 money supply to GDP, which is the broadest definition of money supply, is included in the model to explain whether monetary expansion is identical and cointegrated with national production. The ratio of FCFD (Foreign Currency Fixed Deposit) loans to GDP is to investigate whether the expansion of the credit base, that is, the expansion of the credit volume, has an impact on total production. The reason why both M3 and FCFD loans are considered as a ratio to GDP rather than raw data is to investigate the impact of financial data on GDP sensitively.

Since the distribution of the series is not similar, they are included in the model by taking the logarithm of all three variables and seasonally adjusted by Census x12 method:
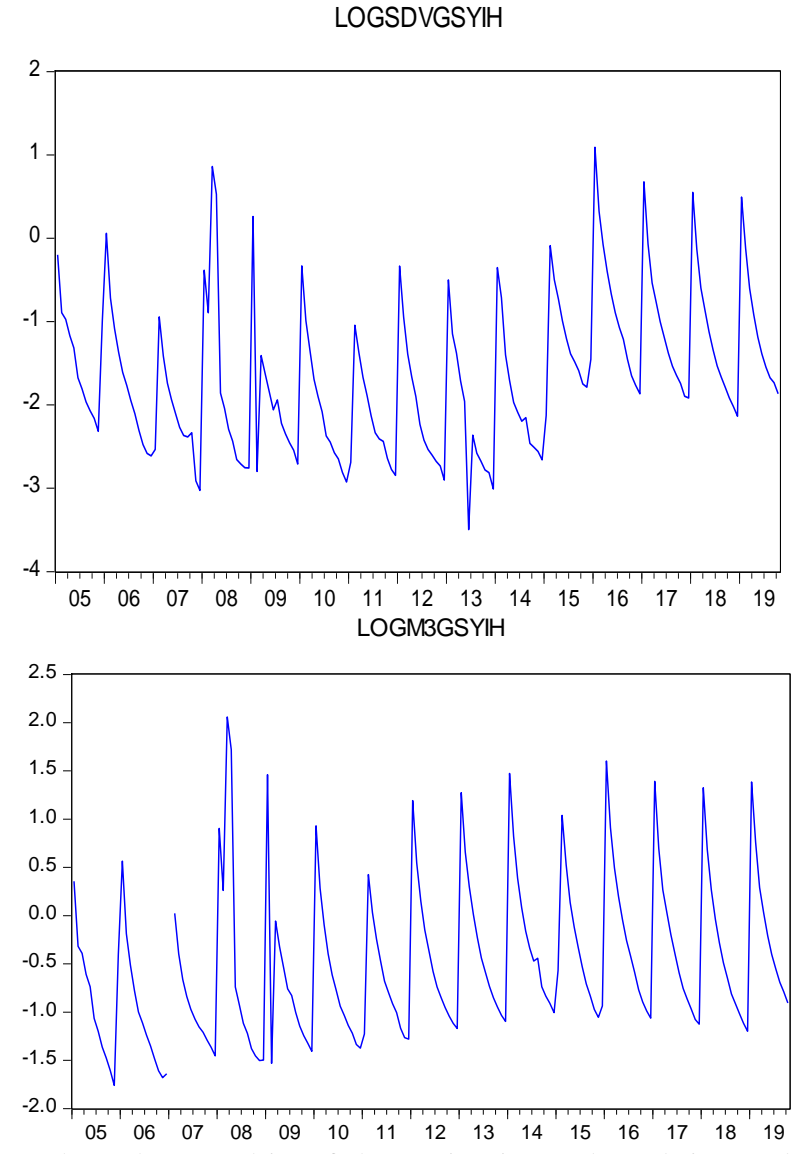

When the graphic of the series is analyzed, it can be said that the series are not stationary, they contain seasonal fluctuations and trends. The tests mentioned above are mandatory to stabilize the series and to understand at which order they are stationary. The logarithmic values of all three variables are included in the model after being seasonality adjusted by Census x 12 method. 


\subsection{Unit Root Analysis}

In time series models, generally variables are not stationary. Regression with non-stationary variables often causes false regression. At the same time, the analysis made with non-stationary variables or the economic interpretation of the forecast is inconsistent. When time series are stationary, their covariance, variance and average do not change over time [43]. In empirical studies, unit root tests are performed to make series stationary. The most common unit root tests in the literature are Augmented Dickey Fuller (ADF), Philips-Perron and Dickey Fuller tests [85]. In the study, extended Phillips-Perron and Dickey-Fuller unit root tests were applied to investigate the stationarity.

The Dickey-Fuller [29] test has a structure that shows whether variables can be expressed in an autoregressive process in the time series. DickeyFuller test is a method that is decided by examining the $t$ statistic and performs a unit root test for the $y$ $=0$ hypothesis with the least square's method. Dickey-Fuller developed the test called the Extended Dickey-Fuller test by including the lagged values of the dependent variable as an independent variable in the model. In this test, for determining the appropriate lag order for the lagged variable, the Schwarz and Akaike criteria are used [43]. Below are the models of the test with and without trend, without constant and with trend, with constant and with trend, respectively:

$$
\begin{gathered}
\Delta Y t=\delta Y_{t-1}+\sum \delta_{i} \Delta Y_{t-1}+\varepsilon_{t}(1) \\
\Delta Y t=\mu+\delta Y_{t-1}+\sum \delta_{i} \Delta Y_{t-1}+\varepsilon_{t}(2) \\
\Delta Y t=\mu+\beta T+\delta Y_{t-1}+\sum \delta_{i} \Delta Y_{t-1}+\varepsilon_{t}(3)
\end{gathered}
$$

Phillips-Perron is developed unit root tests that are commonly used in financial time series. This test differs from ADF in dealing with the problem of serial correlation and changing variance in errors. Instead of adding delayed values to prevent autocorrelation in the ADF equation, the authors rearranged $t$ statistics by estimating the DF equation. Below are the models of the test without constant fixed and trend, with constant and with trend, with constant and trend, respectively:

$\mathrm{Y}_{\mathrm{t}}=\delta \mathrm{Y}_{(\mathrm{t}-1)}+\mathrm{u}_{\mathrm{t}}(4)$

$\mathrm{Y}_{\mathrm{t}}=\beta 1+\delta \mathrm{Y}_{(\mathrm{t}-1)}+\mathrm{u}_{\mathrm{t}}(5)$ [with constant]

$\mathrm{Y}_{\mathrm{t}}=\beta 1+\delta \mathrm{Y}_{(\mathrm{t}-1)}+\beta 2(\mathrm{t}-\mathrm{T} / 2)+\mathrm{u}_{\mathrm{t}}(6)$ [with constant and slope]

The following tables provide the ADF and PP test results for all three variables:
Table 2: GDP - LOGGDP

\begin{tabular}{|c|c|c|c|c|}
\hline Test & \multicolumn{2}{|c|}{ Order } & \multicolumn{2}{c|}{ First difference } \\
\hline & Constant & $\begin{array}{l}\text { Constant } \\
\text { and trend }\end{array}$ & Constant & $\begin{array}{l}\text { Constant } \\
\text { and trend }\end{array}$ \\
\hline ADF & $-1.844078(0)$ & $-3.121372(0)$ & $-6.787583(0)$ & $-6.697111(0)$ \\
\hline PP & -1.9894670 & 0.1094 & $0.0000 *$ & $0.0000 *$ \\
\hline
\end{tabular}

Table 3: M3/GDP- LOGM3GDP

\begin{tabular}{|l|l|l|l|l|}
\hline Test & \multicolumn{2}{|c|}{ Order } & \multicolumn{2}{c|}{ First difference } \\
\hline & Constant & $\begin{array}{c}\text { Constant } \\
\text { and trend }\end{array}$ & Constant & $\begin{array}{c}\text { Constant and } \\
\text { trend }\end{array}$ \\
\hline ADF & $0.592762 \quad(0)$ & $-2.672997(0)$ & $-7.346884(0)$ & $-4.481920(0)$ \\
& 0.9886 & 0.2509 & $0.0000 *$ & $0.0033 *$ \\
\hline PP & 0.271092 & -2.036125 & -5.164065 & -5.448412 \\
& 0.9752 & 0.5717 & $0.0000 *$ & $0.0001 *$ \\
\hline
\end{tabular}

Table 4: FCFD/GDP - LOGFCFDGDP

\begin{tabular}{|l|l|l|l|l|}
\hline Test & \multicolumn{2}{|c|}{ Order } & \multicolumn{2}{c|}{ First difference } \\
\hline & Constant & $\begin{array}{c}\text { Constant } \\
\text { and trend }\end{array}$ & Constant & $\begin{array}{c}\text { Constant and } \\
\text { trend }\end{array}$ \\
\hline ADF & -0.603018 & -2.364719 & -8.519731 & -8.585916 \\
& {$[0.4545]$} & {$[0.3963]$} & {$[0.0000]$} & {$[0.0000]$} \\
\hline PP & -0.588611 & -2.300918 & -8.455948 & -8.513853 \\
& {$[0.4608]$} & {$[0.4303]$} & {$[0.0000]$} & {$[0.0000]$} \\
\hline
\end{tabular}

- *: indicates that at the $5 \%$ level, the $\mathrm{H} 0$

hypothesis is rejected.

- Lag lengths are calculated based on Schwarz information criterion and appropriate lag length is given in parentheses.

It is concluded that all three series contain unit root (H0 hypothesis cannot be rejected) at level values according to both ADF and PP test results. After the first differences of the series were taken, the unit root disappeared (H0 hypothesis is rejected, H1 hypothesis cannot be rejected). Since the test statistics in the level values of the series are greater than the critical value, it is concluded that the series contains the unit root. The series seemed to become stationary when their first differences were taken. The cointegration test was performed by believing that there may be a cointegration relationship among the series that are stationary at the same order I (1).

\subsection{Johansen Cointegration Test}

Cointegration is used to analyze the long-term relationship between economic variables. The variables assumed to have long-term equilibrium relationships, are tested using this method. Cointegration deals with the linear combination of non-stationary variables. According to the cointegration pre-condition, all variables must be integrated of the same order [47].

One of the most used methods in the detection of cointegration in the literature is Johansen analysis [53]. In this method, in vector autoregressive 
(VAR) models, lagged values of a variable itself and all variables in the model are included. The Johansen method is an extended version of the Dickey-Fuller test. In other words, it is expressed in a high order autoregressive process as in the DF test [32].

In Johansen cointegration analysis, the rank of matrix $\pi$ must be known. Here $\Pi$ coefficients are $(\mathrm{NxN})$ dimensional matrix. The matrix is written as $\pi=\alpha \beta$. $\beta$ shows the cointegration matrix, and $\alpha$ is the weights for the parameters of each cointegration vector. In the Johansen cointegration test: If $r(\pi)=$ 0 there is no cointegration, if $r(\pi)=1$ there is 1 cointegration, if $\mathrm{r}(\pi)=2$ there are 2 cointegration relations, $\mathrm{r}(\pi)=\mathrm{r}$ there are $\mathrm{r}$ cointegration relations.

In case of cointegration test, VAR model should be developed by using the level values of the series and the appropriate lag length should be determined.

Before proceeding to the Johansen Cointegration test, the VAR (1) model was developed to determine optimal lag length, and the number of lags was decided based on the Awaike and Swarz information criteria. Up to 12 lag counts, the appropriate lag length was found to be three (3) based on both Awaike and Shcwarz criteria.

Before proceeding to the Johansen Cointegration test, the VAR (1) model was developed to determine optimal lag length, and the optimum lag length was found to be 3 , based on LPE (consecutive harmonized LR test statistic), FPE (last prediction criterion), AIC (Akaike Information Criterion) and the SC (Schwarz information criterion) information criteria:

Table 5: Determining Optimal Lag Length

\begin{tabular}{|l|l|l|l|l|l|l|}
\hline $\begin{array}{l}\text { Lag } \\
\text { Length }\end{array}$ & LogL & LR & FPE & AIC & SC & HQ \\
\hline 0 & 1678.332 & NA & 23233125 & 25.47472 & 25.54024 & 25.50134 \\
\hline 1 & 1195.789 & 935.8399 & 17787.64 & 18.29983 & $18.56191^{*}$ & $18.40633^{*}$ \\
\hline 2 & 1183.295 & 23.66330 & 16874.51 & 18.24689 & 18.70552 & 18.43326 \\
\hline 3 & 1173.755 & $17.63516^{*}$ & $16746.53^{*}$ & $18.23870^{*}$ & 18.89389 & 18.50494 \\
\hline 4 & 1166.654 & 12.80227 & 17253.61 & 18.26749 & 19.11922 & 18.61359 \\
\hline 5 & 1161.891 & 8.370669 & 18428.46 & 18.33169 & 19.37998 & 18.75767 \\
\hline 6 & 1152.950 & 15.30882 & 18489.99 & 18.33258 & 19.57742 & 18.83842 \\
\hline 7 & 1149.740 & 5.350119 & 20253.61 & 18.42030 & 19.86170 & 19.00602 \\
\hline 8 & 1142.805 & 11.24257 & 20991.05 & 18.45160 & 20.08955 & 19.11719 \\
\hline
\end{tabular}

LM test was performed to investigate whether there is autocorrelation in the optimal lag length found. 3rd Lag Length was tested for autocorrelation:
Table 6: Autocorrelation Test

\begin{tabular}{|c|c|c|}
\hline Lag & LM-Stat & Prob \\
\hline 1 & 13.15070 & 0.1559 \\
\hline 2 & 15.21575 & 0.0852 \\
\hline 3 & 10.31326 & 0.3257 \\
\hline 4 & 7.561442 & 0.5789 \\
\hline 5 & 15.49914 & 0.0781 \\
\hline 6 & 10.09251 & 0.3430 \\
\hline 7 & 6.379983 & 0.7014 \\
\hline 8 & 2.017304 & 0.9912 \\
\hline 9 & 4.373142 & 0.8852 \\
\hline 10 & 17.54503 & 0.0408 \\
\hline 11 & 15.07624 & 0.0889 \\
\hline 12 & 6.108068 & 0.7291 \\
\hline
\end{tabular}

According to the hypotheses of the LM autocorrelation test, $\mathrm{H} 0$ hypothesis states that there is autocorrelation at the 5\% significance level, and $\mathrm{H} 1$ hypothesis states that there is no autocorrelation. As a result of the test, it was observed that there was no autocorrelation in the third lag since 7.566811, the value calculated for the 3rd lag, was significant at 5\% level and less than the table value in accordance with the 4th degree of freedom $(\chi 20.005 ; 4=9.448)$. In this case, the $\mathrm{H} 0$ hypothesis cannot be rejected.

To ensure the stationarity condition, Heteroskedastic (variance variance) test was performed to test whether the variance of the error term is the constant for all periods. According to the results of the White test, it was determined that there was no changing variance at $5 \%$ significance level, that is, the variance of error terms was constant for all periods:

Table 7 : White test for Changing Variance

\begin{tabular}{|l|l|c|}
\hline$\chi^{2}$ & Df & Probability \\
\hline 32.52745 & 38 & 0.1187 \\
\hline
\end{tabular}

* Stability condition has been ensured by autocorrelation and variance test, and it has been concluded that the results of the analysis are econometrically significant.

To determine the presence of cointegration and the number of vectors, trace ( $\lambda$ trace) and maximum eigenvalue ( $\lambda \max )$ values are checked. It is decided that cointegration exists when the trace and maximum eigenvalues are greater than the critical values of 5\% significance level. Here $\mathrm{HO}$ hypothesis states that there is no cointegration $(\mathrm{r}=$ $\mathrm{o})$, and $\mathrm{H} 1$ alternative hypothesis states that there is a cointegration relationship $(r>0)$. Within the 
framework of these hypotheses, the findings of the cointegration test are given in the table below:

Table 8: Evaluating hypothesis based on $\Lambda_{\text {trace }}$ values

\begin{tabular}{|l|l|c|l|l|}
\hline $\begin{array}{l}\text { Null } \\
\text { hypothesis } \\
\mathrm{H}_{0}\end{array}$ & $\begin{array}{l}\text { Alternative } \\
\text { Hypothesis } \\
\mathrm{H}_{1}\end{array}$ & $\Lambda_{\text {trace }}$ value & $\begin{array}{l}0.05 \\
\text { critical } \\
\text { value }\end{array}$ & Probability \\
\hline $\mathrm{r}=0$ & $\mathrm{r}>0$ & 86.84169 & 35.19275 & 0.0000 \\
\hline $\mathrm{r}<1$ & $\mathrm{r}>1$ & 41.29980 & 20.26184 & 0.0000 \\
\hline $\mathrm{R}<2$ & $\mathrm{r}>2$ & 3.442907 & 9.164546 & 0.5014 \\
\hline
\end{tabular}

Table 9: Evaluating hypothesis based on $\Lambda_{\max }$ values

\begin{tabular}{|l|l|c|c|c|}
\hline $\begin{array}{l}\text { Null } \\
\text { hypothesis } \\
\mathrm{H}_{0}\end{array}$ & $\begin{array}{l}\text { Alternative } \\
\text { Hypothesis } \\
\mathrm{H}_{1}\end{array}$ & $\Lambda_{\text {trace }}$ value & $\begin{array}{l}0.05 \\
\text { critical } \\
\text { value }\end{array}$ & Probability \\
\hline $\mathrm{r}=0$ & $\mathrm{r}>0$ & 45.54189 & 22.29962 & 0.0000 \\
\hline $\mathrm{r}<1$ & $\mathrm{r}>1$ & 37.85689 & 15.89210 & 0.0000 \\
\hline $\mathrm{r}>2$ & $\mathrm{r}>2$ & 3.442907 & 9.164546 & 0.5014 \\
\hline
\end{tabular}

In the table, $\mathrm{r}$ represents the cointegration number. Critical values are taken from MacKinnon and probability values.

According to the results of the test, trace and maximum eigenvalues are greater than $5 \%$ critical values. At least 1 cointegrated relationship has been found. That is, LOGGDP, LOGM3GDP and LOGFCFDGDP variables are cointegrated. We can understand the long-term relationship between variables by interpreting the following coefficients:

Table 10: Cointegration Coefficients

\begin{tabular}{|l|l|l|l|}
\hline Coefficients & LOGGDP & LOGM3GDP & LOGFCFDGDP \\
\hline Normalized & 1.000000 & -0.102364 & -0.130040 \\
Cointegration & & $(0.00012)$ & $(0.01120)$ \\
Coefficients & & & \\
$\left(\boldsymbol{\beta}^{\prime}\right)$ & & & \\
\hline Adaptation & & & \\
rates & & & \\
coefficients & -3.383243 & & \\
$(\boldsymbol{\alpha})$ & $(0.15533)$ & & \\
\hline
\end{tabular}

Considering the data in the table, we can interpret the long-term relationship AMONG the variables LOGGDP, LOGM3GDP and LOGFCFDGDP. According to the findings of the econometric model, 1 million manats increase in M3 money supply increases GDP by 0.1 and 1 million manats increase in FCFD loans increases GDP by 0.13 .

\subsection{Vector Error Correction Model (Vec)}

To investigate short-term dynamics between LOGGDP, LOGM3GDP and LOGFCFDGDP variables that are cointegrated in the long term, the Vector Error Correction Model has been estimated. The information obtained because of the estimation is given below:

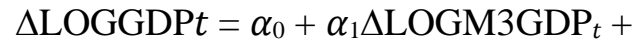 \\ $\alpha_{1} \Delta$ LOGFCFDGDP $_{t} \alpha_{2}$ TREND $+\alpha_{3} E C T_{t-1}+\mathrm{E}_{\mathrm{t}}$ \\ (7) \\ LOGGDP $=-0.002 \mathrm{Ec}_{\mathrm{t}}$ -

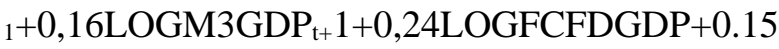 \\ LOGGDP $_{\mathrm{t}-2+} 0.001(8)$ \\ $\mathrm{R}^{2}=0.53$ \\ $\mathrm{R}^{2 \wedge}=0.52$
}

An increase by 1 unit increase in the M3 money supply increases the GDP in one period by 0.16 and after two periods by 0.15 . Significance disappears after 2 periods. The 1-unit increase in FCFD loans increases GDP by 0.24 after 1 period. The fact that the coefficient of the error term is negative, and the $t$ statistic is significant indicates that the error correction model is significant. The fact that the coefficient of the error term is found to be negative indicates that it has returned to the equilibrium in the long term despite deviations from the equilibrium in the short term.

Findings are statistically and econometrically significant and economically have a lower result than expected.

\section{Conclusion}

In the empirical study conducted to measure the impact of financial expansion on GDP in Azerbaijan, firstly the logarithmic values of the variable were taken, since their scales are not close to each other. The results of the unit root tests showed that all three variables are stationary of the order 1. Then, before proceeding to the cointegration test, the optimal lag length was found and diagnostic tests such as autocorrelation and variance were performed for this lag length, and as a result, no problem was found to affect the model. According to the results of Johansen cointegration test, 1 million manat increase in M3 money supply increases GDP by 0.1 , and 1 million manat increase in FCFD loans increases GDP by 0.13 . A significant relationship was found between variables in the short and long term. The results of the error correction model confirmed the short-term significance. According to the cointegration test results, the accuracy of the $\mathrm{H} 0$ hypothesis established within the scope of the study was accepted. (H0: Financial expansion increases GDP. H1: Financial expansion does not increase GDP).

\section{References}

[1] Abu-Bader, Suleiman ve Abu-Qarn, Aamer. S. (2008), "Finan-cial Development and Economic Growth: The 
Egyptian Experience", Journal of Policy Modeling, 30 (2008), pp. 887-898.

[2] Ağayev, S. (2012), "Geçiş Ekonomilerinde Finansal Gelişme ve Ekonomik Büyüme İlişkisi”, Marmara Üniversitesi, İİBF Dergisi, 32(1), 155-164.

[3] Akbulaev, N., \& Huseynova, A. (2019, February). Examining the Role of Credit Volume on Economic Growth: The Case of Azerbaijan. In 37th International Scientific Conference on Economic and Social Development-" Socio Economic Problems of Sustainable Development"-Baku (pp. 1415).

[4] Akimov, A., Wijeweraa, A., ve B. Dollery, (2009), "Financial Development and Economic Growth: EvidencefromTransitonEconomies", Applied Financial Economics, 2009, 19(12), 999-1008.

[5] Akıncı, G., Y. , Akınc1, M. ve Ö. Yılmaz (2014), "Financial Development Economic Growth Nexus: A Panel Data Analysis Upon OECD Countries", Hitotsubashi Journal Of Economics, 55(1), 33-50.

[6] Al-Yousif, Y. K. (2002). Financial Development and Economic Growth: Another Look at the Evidence from Developing Countries. Review of Financial Economics, 11(2), 131-150.

[7] Ang, James B. and McKibbin, Warwick J., (2007), "Financial Liberalization, Financial Sector Development and Growth: Evidence from Malaysia", Journal of Development Economics, Elsevier, Vol. 84(1), 215-233, September.

[8] Anwar, Sajid ve Sun, Sizhong (2011), "Financial Development, Foreign Investment and Economic Growth in Malay-sia", Journal of Asian Economics, 22(2011), pp.335-342.

[9] Arestis, P., Demetriades, P.O. ve Luintel, K.B. (2001). "Financial Development and Economic Growth: The Role of Stock Markets", Journal of Money, Credit, and Banking, 33(1), 16-41.

[10] Arestis, P., Demetriades, P.O., Fattouh, B. ve Mouratidis, K. (2002). "The Impact of Financial Liberalization Policies on Financial Development: Evidence from Developing Economies", International Journal of Finance and Economics, 7(2), 109-121.

[11] Asteriou, D., \& Spanos, K. (2019). The relationship between financial development and economic growth during the recent crisis: Evidence from the EU. Finance Research Letters, 28, 238-245. https://doi.org/10.1016/j.frl.2018.05.011

[12] Asteriou, D., \& Spanos, K. (2019). The relationship between financial development and economic growth during the recent crisis: Evidence from the EU. Finance Research Letters, 28, 238-245. https://doi.org/10.1016/j.frl.2018.05.011

[13] Atje, R. ve Jovanovic, B., (1993). "Stock Markets and Development, European Economic Review, 37(2-3), 632640.

[14] Aydin, K., M., Ak, M. Z. ve N. Altuntaş (2013), "Çevre Ülkelerinde Finansal Gelişme ile Büyüme Arasındaki İlişki: Panel Veri Analizi”. H. Ü. İktisadi ve İdari Bilimler Fakültesi Dergisi, 31(2), $1-14$.

[15] Aydın, Mücahit, and Gürkan Malcıoğlu. "Financial Development and Economic Growth Relationship: The Case of Oecd Countries." Journal of Applied Research in Finance and Economics 2.1 (2016): 1-7.

[16] Beck, T. ve Levine, R. (2004). "Stock Markets, Banks, and Growth: Panel Evidence", Journal of Banking and Finance, (28), 423-442.

[17] Beck, T., Levine, R. ve Loayza, N. (2000). "Finance and the Sources of Growth", Journal of Financial Economics, 58(1-2), 261-300.

[18] Belazreg, W., \& Mtar, K. (2020). Modelling the causal linkages between trade openness, innovation, financial development and economic growth in OECD Countries. Applied Economics Letters, 27(1), 5-8. https://doi.org/10.1080/13504851.2019.160 $\underline{5581}$

[19] Belazreg, W., \& Mtar, K. (2020). Modelling the causal linkages between trade openness, innovation, financial development and economic growth in OECD Countries. Applied Economics Letters, 27(1), 5-8. https://doi.org/10.1080/13504851.2019.160 $\underline{5581}$

[20] Bencivenga, V. R., \& Smith, B. D. (1991). Financial Intermediation and Endogenous Growth. The Review of Economic Studies, 58(2), 195. http://doi.org/10.2307/2297964 
[21] Bhattacharya, P.C. ve Sivasubramanian M.N. (2003) "Financial Development and Economic Growth in India: 1970- 1971 to 1998-1999”, Applied Financial Economics, 13(2), 925-929.

[22] Bozoklu, Ş. ve V. Yılanc1 (2011), "Finansal Gelişme ve İktisadi Büyüme Arasındaki Nedensellik İlişkisi: Gelişmekte Olan Ekonomiler İçin Analiz", Dokuz Eylül Üniversitesi İktisadi ve İdari Bilimler Fakültesi Dergisi, 28(2), 161-187.

[23] Calderon, Cesar ve Liu, Liu (2003), "The Direction of Causality between Financial Development and Economic Growth", Journal of Development Economics, 72 (2003), pp. $321-334$.

[24] Caporale, G. M., Rault, C., Sova, R., \& Sova, A. (2009). Financial development and economic growth: Evidence from ten new EU members (Brunel University Economics and Finance Working Paper Series, No. 09-37). Retrieved from https://www.researchgate.net/publication/4 6450349_Financial_Development_and_Ec onomic_Growth_Evidence_from_Ten_Ne w_EU_Members

[25] Caporale, G.M., Howells, P. ve Soliman, A.M. (2005). "Endogenous Growth Models and Stock Market Development: Evidence From Four Countries", Review of Development Economics, 9(2), 166-176.

[26] Chang, Tsangyao ve Caudill, Steven B. (2005); "Financial Development and Economic Growth: The Case of Taiwan", Applied Economics, Volume 37, Number 12, s. 1329-1335.

[27] Christopoulos, Dimitris K. ve Tsionas, Efthymios G. (2004); "Financial Development and Economic Growth: Evidence from Panel Unit Root and Cointegration Tests", Journal of Development Economics, Volume 73, Issue 1, s. 55-74.

[28] Cojacaru, L. Hoffman, S. ve J. Miller, (2011), "Financial Development and Economic Growth: Empirical Evidence from CEE and CIS Countries", Working Paper Series, 22, 1-30.

[29] Demetriades, P. O., \& Hussein, K. A. (1996). Does financial development cause economic growth? Time-series evidence from 16 countries. Journal of
Development Economics, 51(2), 387-411. http://doi.org/10.1016/S0304-

3878(96)00421-X

[30] Demirguc-Kunt, A. ve Maksimovic, V. (1998). "Law, Finance, and Firm Growth", Journal of Finance, 53(6), 2107-2137.

[31] Dickey, D. ve FullerW. A. (1981). "Likelihood Ratio Statistics for Autoregressive Time Series with A Unit Root", Econometrica, 49(4), ss. 1057-1072.

[32] Dickey, D.A. ve Fuller W.A. (1979). "Distribution of The Estimators for Autoregressive Time Series with a Unit Root", Journal of the American Statistical Association, 74, 427-431.

[33] Dritsakis, N., Adamopoulos, A.. (2004). "Financial Development and Economic Growth in Greece: An Empirical Investigation with Granger Causality Analysis", International Economic Journal, 18(4), 547-559.

[34] Dudian, M., P., ve A. Raluca, (2013), "Financial Development and Economic Growth in Central and Eastern Europe», Theoretical and Applied Economics, 20 (8/585), 59-68.

[35] Durusu-Ciftci, D., Ispir, M. S., \& Yetkiner, H. (2017). Financial development and economic growth: Some theory and more evidence. Jour nal of Policy Modeling, 290-306. https://doi.org/10.1016/j.jpolmod.2016.08. 001

[36] E Levine, R. (1997). Financial Development and Economic Growth: Views and Agenda. Journal of Economic Literature, 35(2), 688-726.

[37] Engle, R. F. ve Granger C. W. J. (1987). "Cointegration and Error Correction: Representation, Estimation and Testing", Econometrica, 55 (2), 251-276.

[38] Enisan, A. A. ve Olufisayo, A.O. (2009). "Stock Market Development and Economic Growth: Evidence from Seven Sub-Saharan African Countries", Journal of Economics and Business, 61(2), MarchApril, 162-171.

[39] Eren, B. M., Taspinar, N., \& Gokmenoglu, K. K. (2019). The impact of financial development and economic growth on renewable energy consumption: Empirical analysis of India. Science of the Total Environment, 663, 189-197. 
https://doi.org/10.1016/j.scitotenv.2019.01. $\underline{323}$

[40] Fink, G., Haiss, P. ve G. Vuksic, (2009), "Contribution of Financial Market Segments at Different Stages of Development: Transition, Cohesion and Mature Economies Compared", Journal of Financial Stability, 5 (4), 431-455.

[41] Fink, G., Haiss, P. ve Hristoforova, S. (2003). Bond Markets and Economic Growth, Research Institute for European Affairs Working Paper, 49. April.

[42] Francis, X. (1999). On the power of Dickey-Fuller tests against fractional alternatives. Business Cycles: Durations, Dynamics, and Forecasting, 258.

[43] Fry, M. F. (1978). Money and Capital or Financial Depeening in Economic Development? Journal of Money, Credit and Banking, 10(4), 464475.

[44] Göktaş, Ö. (2005). Teorik ve Uygulamalı Zaman Serileri Analizi. İstanbul: Beşir Kitabevi.

[45] Goldsmith, R. W. (1959). Financial Structure and Development as a Subject for International Comparative Study. In National Bureau of Economic Research (Vol. The Compar, pp. 114-123). NBER.

[46] Gregorio, J. D., \& Guidotti, P. E. (1995). Financial development and economic growth. World Development, 23(3), 433-448. doi: 10.1016/0305750X(94)00132-1

[47] Gujarati, D.N. (1999) Temel Ekonometri, (Çev. Ü. Şenesen ve G.G. Şenesen). İstanbul, Literatür Yayınları.

[48] Gurley, J.G. ve Shaw, E.S. (1955). "Financial Aspects of Economic Development", American Economic Review, (45), 515-538.

[49] Hagmayr, B., Haiss, P. ve K. Sümegi, (2007), "Financial Sector Development and Economic GrowthEvidence for Southeastern Europe", Research Gate, 2007, http://www.researchgate.net/publication/22 8255390_Financial_Sector_Development_ and Economic Growth Evidence for Sou theastern Europe ,ErişimTarihi: 04.11.2015.

[50] Henry, P.B. (2000),.“Do Stock Market Liberalizations Cause Investment Booms?", Journal of Financial Economics, 58(1-2), 301-334.
[51] Humbatova, S. I., Ahmadov, F. S., Seyfullayev, I. Z., \& Hajiyev, N. G. O. (2020). The relationship between electricity consumption and economic growth: Evidence from Azerbaijan. International Journal of Energy Economics and Policy, 10(1), 436.

[52] Johansen S. ve Juselius, K. (1990). "Maximum Likelihood Estimation and Inference on Cointegration with Application to the Demand for Money", Oxford Bulletin of Economics and Statistics, 52(2), 169-210.

[53] Johansen, S. (1988). "Statistical Analysis of Cointegration Vectors, Journal of Economic Dynamics and Control, 12(23), 231-254.

[54] Kandır, S. Y., İskenderoğlu, Ö., \& Önal, Y. B. (2007). Finansal Gelişme ve Ekonomik Büyüme Arasındaki İlişkinin Araştırılması. Çukurova Üniversitesi Sosyal Bilimler Enstitüsü Dergisi, 16(2), 311-326.

[55] Kar, M., Pentecost, E. J. (2000). Financial Development and Economic Growth in Turkey: Further Evidence on The Causality Issue, Loughborough University Economic Research Paper, December. (Erişim Tarihi 09.02.2009). (http://www.econturk.org/muhsinkar.pdf).

[56] Kenourgios, D., ve A. Samitas, (2007), "Financial Development and Economic Growth in a Transition Economy: Evidence for Poland", Journal of Financial Decision Making, 3(1), 35-48.

[57] King, R. G., \& Levine, R. (1993). Finance and Growth: Schumpeter Might Be Right. The Quarterly Journal of Economics, 108(3), 717-737. http://doi.org/10.2307/2118406

[58] King, R. G., \& Levine, R. (1993). Finance, entrepreneurship and growth. Journal of Monetary Economics, 32(3), 513-542. http://doi.org/10.1016/03043932(93)90028

[59] Lawal, A. I., Nwanji, T. I., Asaleye, A., \& Ahmed, V. (2016). Economic growth, financial development and trade openness in Nigeria: An application of the ARDL bound testing approach. Cogent Economics \& Finance, 4(1), 1258810. https://doi.org/10.1080/23322039.2016.125 $\underline{8810}$ 
[60] Lawal, A. I., Nwanji, T. I., Asaleye, A., \& Ahmed, V. (2016). Economic growth, financial development and trade openness in Nigeria: An application of the ARDL bound testing approach. Cogent Economics \& Finance, 4(1), 1258810. https://doi.org/10.1080/23322039.2016.125 8810

[61] Levine, R. ve Zervos, S., (1998). "Stock Markets, Banks, and Economic Growth", American Economic Review, $88(3), 537-558$.

[62] Lucas, R., E., (1988), "On the Mechanics of Economic Development", Journal of Monetary Economics, 22(1), 342.

[63] Luintel, Kul B., Khan, Mosahid, Leon-Gonzalez, Roberto ve Li, Guangjie (2016), "Financial Development, Structure and Growth: New Data Method and Results", Journal of In-ternational Financial Markets, Institutions \& Money, 43 (2016), pp.95-112.

[64] Mahmood, H., \& Alkahtani, N. S. (2018). Human resource, financial market development and economic growth in Saudi Arabia: a role of human capital. Economic annals-XXI, (169), 31-34.

[65] Mccaig, B. ve Stengos, T. (2005). "Financial Intermediation and Growth: Some Robustness Results", Economics Letters, 88(3), 306-312.

[66] Mckinnon, R., (1973). Money and Capital in Economic Development, Washington D.C., The Brookings Institution.

[67] Menyah, Kojo, Nazlıoğlu, Şaban ve Wolde-Rufael, Yemane (2014), "Financial Development, Trade Openness and Economic Growth in African Countries: New Insights from a Panel Causality Approach", Economic Modelling, 37(2014), pp.386-394.

[68] Mukhtarov, S., Mammadov, I., \& Hamidov, H. (2019). THE IMPACT OF GOVERNMENT EDUCATION EXPENDITURES ON ECONOMIC GROWTH: EVIDINCE FROM AZERBAIJAN. Economic and Social Development: Book of Proceedings, 426434.

[69] Müslümov, A. ve Aras, G. (2002). "Sermaye Piyasası Gelişmesi ve Ekonomik
Büyüme Arasında Nedensellik İlişkisi: OECD Ülkeleri Örneği”, İktisat İşletme Finans, 17(198), 90- 100.

[70] Naceur, Samy Ben, and Samir Ghazouani. "Stock markets, banks, and economic growth: Empirical evidence from the MENA region." Research in International Business and Finance 21.2 (2007): 297-315.

[71] Ndikumana, L. (2005). "Financial Development, Financial Structure, and Domestic Investment: International Evidence", Journal of International Money and Finance, 24(4), 651-673.

[72] Obradovic, S. ve M. Grbic, (2015), "Causality Relationship Between Financial Intermediation by Banks and Econo-mic Growth: EvindenceFromSerbia”, Prague Economic Papers, 24(1), 60-72.

[73] Oskonbaeva, Z. (2018). Causal link between financial development and economic growth: the case of transition countries. Financial and credit activity: problems of theory and practice, 3(26), 418-424.

[74] Oskonbaeva, Z. (2018). Causal link between financial development and economic growth: the case of transition countries. Financial and credit activity: problems of theory and practice, 3(26), 418-424.

[75] Patrick, H. T. (1966), Financial Development And Economic Growth in Underdeveloped Countries, Economic Development and Cultural Change, 14, 174-189.

[76] Petkovsk, M. ve J. Kjokevski, (2014), "Does Banking Sector Development Promote Economic Growth? Am Emprical Analysis for Selected Countries in Central and South Eastern Europe",Economic Research, 27(1), 55-66.

[77] Rioja, Felix ve Valev, Neven (2004); "Finance and the Sources of Growth at Various Stages of Economic Development", Economic Inquiry, Vol. 42, No. 1, s. 127-140.

[78] Robinson, J. (1952), "The Generalization of the General Theory", In the Rate of Interest and Other Essays, London, Macmillan, 69-142.

[79] Rousseau, P.L. ve Vuthipadadorn, D. (2005), "Finance, Investment, and Growth: Time Series Evidence from 10 
Asian Economies", Journal of Macroeconomics, (27), 87-106.

[80] Samargandi, Nahla, Fidrmuc, Jan ve Ghosh, Sugata (2015), "Is the Relationship Between Financial Development and Economic Growth Monotonic? Evidence from a Sample of Middle-Income Countries", World Development, 68, pp. 66-81.

[81] Schumpeter, J. A., (1912), The Theory of Economic Development, Cambridge: Harvard University Press.

[82] Schumpeter, J. A., (1934), The Theory of Economic Development; An Inquiry into Profits, Capital, Credit, Interest, and the Business Cycle, Çev. Opie, R. Cambridge: Harvard University Press.

[83] Shahbaz, M., Ahmed, N. ve Ali L. (2008). "Stock market Development and Economic Growth: ARDL Causality in Pakistan", International Research Journal of Finance and Economics, 14, 182-195.

[84] Shahbaz, Muhammed, Tiwari, Aviral Kumar ve Nasir, Mu-hammed (2013), "The Effects of Financial Development, Economic Growth, Coal Consumption and Trade Openness on CO2 Emissions in South Africa", Energy Policy, 61(2013), pp.1452-1459.

[85] Shan, J. Z., Morris, A. G., \& Sun, F. (2001). Financial Development and Economic Growth: An Egg-and-Chicken Problem? Review of International Economics, 9(3), 443-454. http://doi.org/10.1111/1467-9396.00291

[86] Shaw, E. (1973). Financial Deepening in Economic Development, Oxford University Press, London.

[87] Soultaneva, A., (2011), "Financial Intermediation and Economic Growth: Evidence from the Baltic Countries", Umea Economic Studies, 187, 1-11.

[88] Winkler, A., (2009), "Southeastern Europe: Financial Deepening, Foreign Banks and Sudden Stops in Capital Flows", Focus on European Economic Integration, 1, 84-97

[89] Wolde- Rufael, Yemane (2009), "Re-examining the financial development and economic growth nexus in Kenya", Economic Modelling, 26(2009), pp.11401146.

[90] Yurdakul, F. (2000). Yapisal kırılmaların varlığı durumunda geliştirilen birim-kök testleri. Gazi Universitesi Iktisadi ve Idari Bilimler Fakultesi Dergisi, 2(2).

[91] Zhang, Jin, Wang, Lanfang ve Wang, Susheng (2012), "Financial Development and Economic Growth: Recent Evidence from China", Journal of Comparative Economics, 40 (2012), pp.393-412.

\section{Creative Commons Attribution License 4.0 (Attribution 4.0 International, CC BY 4.0)}

This article is published under the terms of the Creative Commons Attribution License 4.0 https://creativecommons.org/licenses/by/4.0/deed.en_US 